\title{
Roost characteristics and clustering behavior of western red bats (Lasiurus blossevillii) in southwestern New Mexico
}

\author{
Brett R. Andersen ${ }^{1, *}$ and Keith Geluso ${ }^{1}$ \\ ${ }^{1}$ Biology Department, University of Nebraska at Kearney, Kearney, NE 68849
}

\begin{abstract}
AвsTRACT.-The western red bat (Lasiurus blossevillii) is a foliage-roosting species of riparian habitats in arid regions of the southwestern United States. Only limited published anecdotal observations exist for roost sites used by this species. Western red bats were split taxonomically from the eastern red bat (Lasiurus borealis) in 1988, but summaries of roosting behaviors for western red bats still appear to stem from former associations with the commonly studied eastern red bat. Our study represents the first comprehensive research on the roosting ecology of western red bats. We radio-tracked 14 adult bats to 19 different day roosts along the Mimbres River of southwestern New Mexico. While we documented that western red bats had an affinity for densely foliated trees $(79 \%)$, we did not detect any selection for tree species or size. At our study site, western red bats roosted in cottonwoods (47\%, Populus spp.), velvet ash (21\%, Fraxinus velutina), box elder (16\%, Acer negundo), and red mulberry $(16 \%$, Morus rubra). We also described clustering behavior, where groups of 2-3 adults roosted in direct contact with one another. Although the species was deemed to roost solitarily, the frequency of clustering behavior in our study suggests otherwise. If bats were observed in clusters, they typically exhibited greater roosting fidelity than solitary individuals. Because arid riparian corridors in the southwestern United States generally are considered threatened systems, protection and preservation of mechanisms that create and maintain the diversity of these riparian corridors is necessary for the survival of this uncommon and poorly understood species.
\end{abstract}

REsumen.-El murciélago rojo del desierto (Lasiurus blossevillii) es una especie de hábitat ribereño que anida en follajes de las regiones áridas del suroeste de los Estados Unidos. Existen escasas observaciones anecdóticas de los sitios donde percha esta especie. Los murciélagos rojos del desierto se separaron taxonómicamente del murciélago colorado del este (Lasiurus borealis) en 1988. Sin embargo, la información sobre la conducta de percha de Lasiurus blossevillii aún parece surgir de antiguas asociaciones con el murciélago Lasiurus borealis. Nuestra investigación representa el primer estudio exhaustivo sobre la ecología de percha de Lasiurus blossevillii. Realizamos radio monitoreos de 14 murciélagos adultos en 19 diferentes sitios de percha diurnos a lo largo del río Mimbres, al suroeste de Nuevo México. Encontramos que Lasiurus blossevillii muestra afinidad hacia los árboles frondosos (79\%). No obstante, no detectamos afinidad alguna hacia una especie o tamaño de árbol en particular. En nuestro sitio de estudio, Lasiurus blossevillii percha en álamos (47\%, Populus spp.), en fresnos terciopelo (21\%, Fraxinus velutina), en arces negundos (16\%, Acer negundo) y en moras rojas (16\%, Morus rubra). También, describimos la conducta de agrupamiento, en la que grupos de 2 a 3 individuos adultos se encontraron perchando en contacto directo entre sí. Aunque, anteriormente se consideraba que esta especie perchaba solitariamente, la frecuencia de agrupamientos en nuestro estudio sugiere lo contrario. Los murciélagos observados en grupos, exhibieron mayor fidelidad al sitio de percha que los individuos solitarios. Debido a que, por lo general, las zonas ribereñas áridas del suroeste de los Estados Unidos se consideran sistemas amenazados, la protección y la preservación de los mecanismos que crean y mantienen la diversidad en estas zonas ribereñas es necesaria para la supervivencia de esta especie poco común y poco conocida.

Day roosts serve a variety of important functions necessary for the survival of bats, including protection from predators, shelter from adverse environmental conditions, and refuge to bear and raise offspring (Humphrey 1975, Kunz and Lumsden 2003). Of the various structures used as day roosts, both natural and artificial, trees are used by many bats. In the continental United States, 7 species of lasiurids have specialized adaptations in their morphology, behavior, and reproduction to exploit the foliage of trees for roosts (Carter and Menzel 2007, Altringham 2011, Harvey et al. 2011). Despite technological advances and increased interest in the roosting habits of bats since the early 1980s (Fenton 1997), few studies have investigated roost selection of lasiurids (Kalcounis-Rüppell et al. 2005, Carter and

*Corresponding author: brett.andersen@ttu.edu

orcid.org/0000-0002-7606-791X 
Menzel 2007). However, because climatic shifts, changing habitats, and human disturbances pose threats to this specialized group of bats (Barclay et al. 2007, Kunz et al. 2007, Arnett et al. 2008), understanding their roosting habits will be important for their conservation, as some populations are declining or are suspected to decline (Carter et al. 2003, Carter and Menzel 2007, Arnett et al. 2008, Frick et al. 2017). One such species with scant roosting data that resides in threatened habitats is the western red bat (Lasiurus blossevillii).

The western red bat occurs from northern California to central Argentina (Shump and Shump 1982, Cryan 2003, Gardner and Handley 2007). In the United States, the majority of its range occurs in the arid Southwest (Adams 2003). Presence of foliage-roosting western red bats in arid ecosystems often correlates with deciduous riparian corridors (Findley et al. 1975, Adams 2003), and only a few published observations on roosts and roosting behavior are known throughout the entire distribution (Grinnell 1918, Hargrave 1944, Orr 1950, Constantine 1959, Carter and Menzel 2007). A limited understanding of roosting habits of western red bats likely stems in part from their taxonomic split from eastern red bats (Lasiurus borealis). Red bats once were considered a single species distributed across parts of North and South America, comprising 5 subspecies (Shump and Shump 1982). Two of these subspecies, an eastern clade $(L . b$. borealis) and a western clade (L. b. teleotis; Hall 1981, Shump and Shump 1982), occurred in the United States. Phylogenetic analyses demonstrated that these 2 clades represent distinct species, L. borealis, the eastern red bat, and L. blossevillii, the western red bat (Baker et al. 1988, Morales and Bickham 1995). Although the eastern red bat is the most studied foliage-roosting bat in the United States, few published studies have investigated the natural history of the western red bat (Cryan 2003, Carter and Menzel 2007). In 1998, the Western Bat Working Group emphasized the need to prioritize funding for the species in all parts of its range in the United States (Adams 2003).

In New Mexico, few captures exist for western red bats, and not a single roost is known in the state (Constantine 1961, Jones 1961, 1966, Mumford and Zimmerman 1963, Jones and Suttkus 1972, Findley et al. 1975,
Cook 1986, Valdez et al. 1999). The western red bat is a species of greatest conservation need in New Mexico due to a paucity of ecological data for this uncommon bat (NMDGF 2006). Excluding an extralimital record in Texas (Genoways and Baker 1988), southwestern New Mexico represents the eastern distributional extent for western red bats in the United States (Adams 2003). Understanding the roosting ecology of this species is imperative for conservation and long-term success of populations, as many arid riparian habitats are threatened throughout the southwestern United States (Stromberg et al. 2012, Gori et al. 2014). In this study, we identified roost characteristics of trees used by western red bats along the Mimbres River in southwestern New Mexico and described clustering behavior of adults at these locations.

\section{Methods \\ Study Area}

From 13 May to 10 June 2015 and from 19 May to 9 June 2016, we examined roost characteristics and behaviors of western red bats along the Mimbres River, Luna County, in southwestern New Mexico. Our netting efforts were centered around 2 areas along a $3.25-\mathrm{km}$ stretch of river. At the northern netting site $\left(32.58689^{\circ} \mathrm{N}, 107.92105^{\circ} \mathrm{W}\right.$; WGS84; $1539 \mathrm{~m}$ elevation), the river flowed continually during the study, with the river about 1 to $3 \mathrm{~m}$ wide and 2 to $4 \mathrm{~cm}$ deep in most areas. This area also contained an irrigation diversion that generated a pool of water approximately $18 \mathrm{~m}$ across. Shallow pools were created by the intermittent flow of the river at the southern netting site $\left(32.57600^{\circ} \mathrm{N}, 107.92145^{\circ} \mathrm{W} ; 1529 \mathrm{~m}\right.$ elevation) before the river became completely subterranean. The narrow riparian corridor was dominated by large cottonwoods (Populus spp.) and shrub-like willows (Salix spp.). Near the southern netting site, a 7.5-ha grove of trees with a fairly open understory provided the greatest density of trees in the immediate area. This deciduous grove was dominated by velvet ash (Fraxinus velutina), but also contained box elder (Acer negundo), walnut (Juglans spp.), and red mulberry (Morus rubra). Several large cottonwoods also were scattered across a sacaton grassland (Sporobolus wrightii) that covered the majority of the floodplain in the area. Beyond the floodplain, 
a honey mesquite (Prosopis glandulosa) scrubland offered no roosts for foliage-roosting bats.

\section{Bat Capture and Radiotelemetry}

We captured bats in mist nets (Avinet Inc., Portland, ME) that ranged in size from 6 to $18 \mathrm{~m}$ and were placed across calm surfaces on the river, in constriction points of riparian flyways and beneath densely foliated trees, especially when the aforementioned areas were illuminated with moonlight. We recorded forearm length $(\mathrm{mm})$, weight $(\mathrm{g})$, sex, and reproductive status (nonreproductive or pregnant) of each captured individual. We used surgical adhesive (Perma-Type Company, Inc., Plainville, CT) to affix a 0.27 0.35-g radio transmitter (Holohil Systems Ltd., Ontario, Canada) to the backs of western red bats after fur was clipped between the scapulae. Because multiple bats were observed roosting together in trees in 2015 , a uniquely painted, split aluminum alloy bat ring (size $2.4 \mathrm{~mm}$; Porzana Ltd., United Kingdom) was placed on each bat in 2016 for easier identification of tagged individuals in the event that untagged individuals were identified in the roost. Capture and handling of bats was conducted under animal care and use protocol \#020614 approved by the University of Nebraska at Kearney and met guidelines recommended by the American Society of Mammalogists (Sikes et al. 2011).

We used telemetry receivers (R-1000, Communication Specialists Inc., Orange, CA) and 3- or 5-element Yagi antennas to track bats to roost trees. On each day signals were detected, we identified the roost trees, and if possible, visually located bats in the foliage. For some roosts, we identified individuals roosting in direct contact with one another and classified these groups as clusters. When signals were not detected, previous roosts were revisited, and if a bat was observed possessing a color-coded forearm band, we could determine whether the radio transmitter was shed or the battery was dead.

\section{Roost Tree Metrics}

Once each roost tree was identified, we recorded species, condition (live or dead), and diameter at breast height (DBH). Tree and roost heights were measured using a clinometer (Suunto Co., Helsinki, Finland). Roost orientation was determined by standing at the base of the tree and assessing the compass direction of the roost from that position. We visually estimated the distance from the location of each bat to the outer edge of the canopy of the roost tree, and we qualitatively recorded foliage density of roost trees depending on the amount of light penetrating to the ground at midday (dense, $>75 \%$ shade; moderate, $50 \%-75 \%$ shade; sparse, $<50 \%$ shade). Distances from capture sites to roosts and any subsequent roosts were measured in ArcMap 10.3.1 (Esri, Redlands, CA).

We compared characteristics of roost trees and surrounding trees by recording the species, condition (live or dead), and diameter of all trees with a DBH $>9.5 \mathrm{~cm}$ within a 0.1-ha circular plot surrounding the roost (Perry and Thill 2007). To compare characteristics of roost trees to random trees, identical measurements were taken on the first tree with a DBH $>9.5 \mathrm{~cm}$ selected at a distance between $50 \mathrm{~m}$ and $100 \mathrm{~m}$ from the roost (Willis and Brigham 2005). Due to the limited number of trees at the study site and the presence of isolated trees in the sacaton grasslands, some comparison trees $(n=6)$ were not measured because they were either not within the target distance $(>100 \mathrm{~m})$ or they were in close proximity $(<50 \mathrm{~m})$ to a roost tree causing overlap in analysis. After noticing trends in roost selection, we chose 5 trees that met our criteria and visually scanned them for presence of bats; those trees were not included in statistical analyses.

\section{Statistical Analysis}

To evaluate selection of tree species and foliage density by western red bats, we adopted an electivity index utilized in prey selection of fish (Strauss 1979):

$$
L=r_{i}-p_{i},
$$

where $r_{i}$ and $p_{i}$ represent relative abundance of each characteristic of trees selected for roosts and those available in the environment, respectively. The continuous variable $L$ can range from +1 to -1 , where values close to +1 indicate selection, values close to -1 indicate avoidance, and values near 0 indicate lack of selection (Strauss 1979). A threshold value of \pm 0.15 was used to determine selection for or against certain characteristics (Dettmers and Stein 1992, Sullivan et al. 2011, 2012). 
To compare differences between roost orientation and random direction, we used a Rayleigh's test (Zar 1999). We conducted Mann-Whitney-Wilcoxon tests in RStudio (Version 0.99.903, Boston, MA) with a 95\% confidence interval to assess differences in characteristics between roost trees and random trees. We also compared roost characteristics between solitary and clustering bats. If multiple tagged bats were observed using a roost tree, we only used measurements of the tree (DBH, height, foliage density, etc.) once in averages and statistical analyses. However, when solitary and clustering roosts were compared, if a tree possessed both solitary and clustering bats, it was factored in both categories.

\section{RESUlTS}

\section{Radiotelemetry}

We tracked a total of 14 adult western red bats (13 females, 1 male) to 19 different roost trees. All roosts were located in live deciduous trees in the floodplain along the Mimbres River. We visually confirmed western red bats in 18 of 19 trees, and all bats were located within $1.5 \mathrm{~m}$ of the canopy edge. All roosts were shaded from above by dense leaves or clumps of samaras but open from below, allowing for easy observation from the ground. Average roost height was $9.4 \mathrm{~m}$ (SE 1.0) above the ground, but ranged from 3.0 to $17.1 \mathrm{~m}$. Roost sites were oriented in all directions from the trunk, and we did not detect a specific orientation for roosts in trees (Rayleigh's $Z=$ $0.318, P=0.375)$. One roost site used by a cluster in May 2016 was revisited on 23 June 2016 , and 4 juvenile western red bats were observed in the exact location where a radiotagged bat roosted earlier that month.

\section{Roost Metrics}

Roosts consisted of cottonwoods (47\%), velvet ash $(21 \%)$, box elder (16\%), and red mulberry $(16 \%)$. We did not detect any tree species that exceeded the \pm 0.15 threshold for selection (Fig. 1). However, when comparing foliage density to surrounding trees, we found that western red bats selected trees with dense foliage (i.e., $>75 \%$ shade, $L=0.33$ ) and avoided trees with sparse foilage (i.e., $<50 \%$ shade, $L=-0.22$; Fig. 1 ). We did not detect a difference in average tree height
(16.7 m, SE 1.4) or DBH (89.6 cm, SE 15.3) from randomly selected trees (Table 1). The number of trees surrounding roosts within the 0.1-ha circular plot were significantly fewer than those surrounding randomly selected trees $(P=0.04)$. Average roost distance from the capture site was $0.2 \mathrm{~km}$ (SE 0.1 ), and distance between roosts was $0.1 \mathrm{~km}$ (SE 0.03).

While tracking western red bats to roosts at the study site, we developed a search image for potential roost trees. We selected densely foliated trees and searched the edge of the canopy for untagged western red bats. After scanning a total of 5 trees that met our criteria, we identified 2 solitary bats roosting in the foliage of a cottonwood. We stretched mist nets under these possible roosts and caught, tagged, and tracked 3 western red bats to the densely foliated overstory trees.

\section{Clustering Behavior}

Upon locating bats in roost trees, we observed that 6 roosts possessed multiple bats in small clusters of 2 or 3 adults. Groups of 2 individuals were observed roosting face to face (Fig. 2A, 2B) and face to back (Fig. 2C). Two groups of 3 individuals each exhibited all bats face to face (Fig. 2D). One group consisted of 2 tagged bats tracked individually to 3 different trees prior to being observed in a cluster $4 \mathrm{~d}$ after capture. Although untagged bats in clusters could not be confirmed as the same bat each day, it can be assumed, based on the presence of the same tagged bat, that these were also the same individuals. Clusters of bats were observed in cottonwoods and box elders. In 2016, a cluster of 3 bats consisting of 1 tagged adult female, 1 tagged adult male, and 1 unidentified bat was observed in almost the exact location of a large cottonwood where a cluster of 3 , containing 1 tagged female bat, was observed a year earlier in 2015 .

Unlike solitary bats, which only remained in a roost for a maximum of 3 days, clustered bats remained in roosts consistently throughout the duration of the study, unless disturbed. In comparing roosts between clustering and solitary bats, we did not detect a difference in tree height, roost height, or DBH (Table 2). The number of trees surrounding roosts was similar $(P=0.14)$, but trees surrounding cluster roosts were significantly smaller in diameter than those surrounding solitary roosts $(P<0.01)$. 

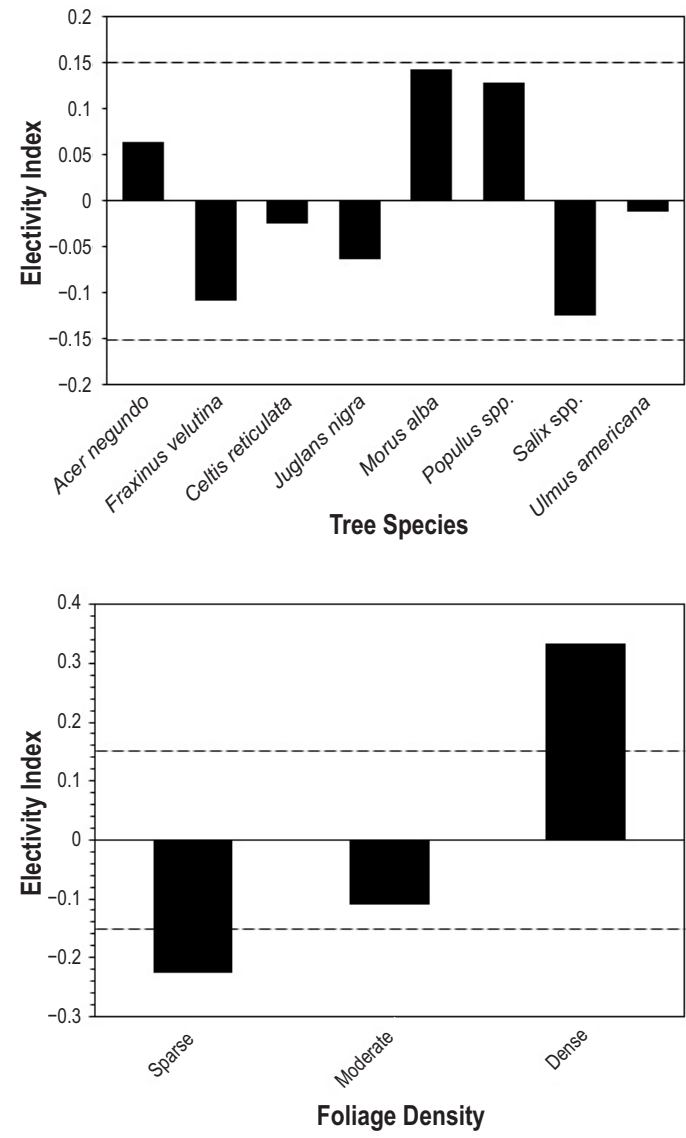

Fig. 1. Electivity index adopted from Strauss (1979) to evaluate roost selection of western red bats (Lasiurus blossevillii) in southwestern New Mexico. Selection for roost characteristics is significant if the index threshold value is greater than 0.15 , and selection against is significant if the index threshold value is less than -0.15 (Dettmers and Stein 1992). No selection was evident among tree species (top), but selection was detected for dense foliage (bottom).

\section{Discussion}

Western red bats in southwestern New Mexico regularly roosted in densely foliated deciduous trees with no apparent selection for tree species or tree size. Multiple observations of adults clustering at roost sites contradicts previous descriptions of the species being solitary. Our data on roost selection and behavior differ from those on other species in the genus, including the closely related eastern red bat. In addition, we observed differences in roost fidelity between solitary and clustering western red bats in the study area.
TABLE 1. Comparison of roost characteristics for western red bats (Lasiurus blossevillii) between roost trees and random trees along the Mimbres River in southwestern New Mexico. Results are significant if $P<0.05$. Means are given with standard error in parentheses.

\begin{tabular}{lclc}
\hline $\begin{array}{l}\text { Tree } \\
\text { characteristic }\end{array}$ & Roost & Random & $P$ \\
\hline Height $(\mathrm{m})$ & $16.7(1.5)$ & $17.2(1.9)$ & 0.48 \\
DBH $(\mathrm{cm})$ & $89.7(15.4)$ & $72.1(10.4)$ & 0.35 \\
No. of surrounding & $9.1(1.7)$ & $13.1(2.7)$ & 0.04 \\
$\quad \begin{array}{l}\text { trees } \\
\text { Surrounding }\end{array}$ & $48.9(2.6)$ & $43.3(2.0)$ & 0.17 \\
$\quad$ tree DBH $(\mathrm{cm})$ & & & \\
\hline
\end{tabular}

Our data represent the first roosts reported in New Mexico and the most comprehensive study on roosts used by this species throughout its distribution.

Unlike other lasiurids that commonly select for large trees in their environment (Mager and Nelson 2001, Elmore et al. 2004, Hein et al. 2008a), western red bats did not select trees differing in size from random trees, but they did select greater foliage density. A lack of use of large trees might be explained by the presence of large trees with sparse foliage (Populus spp.) and small leaves (Fraxinus velutina and Juglans spp.). Moreover, several isolated cottonwood trees used as roosts in sacaton grasslands possessed denser foliage than many cottonwoods along the river corridor. Additionally, roosting sites in canopies occurred near dense bundles of leaves or clumps of samaras that provided protection from above and were open from below. Such roost characteristics have been described for other lasiurids including eastern red, hoary (Lasiurus cinereus), and northern yellow (Lasiurus intermedius) bats (Constantine 1959, 1966, Saugey et al. 1998, Hutchinson and Lacki 2000, Mager and Nelson 2001, Willis and Brigham 2005, Coleman et al. 2012). These types of roosts likely provide shade, protection from precipitation and strong winds, easy departure in case of disturbance, and easy access upon arrival (Walsberg 1986, Hutchinson and Lacki 2000, Mager and Nelson 2001, Willis and Brigham 2005, Mormann and Robbins 2007). We observed that, with patience, bats with radio tags could be discovered in trees, but roosts in dense bundles of leaves or clumps of samaras were difficult to find and likely aid in camouflage and protection from predators as well, especially when viewed from the top or 


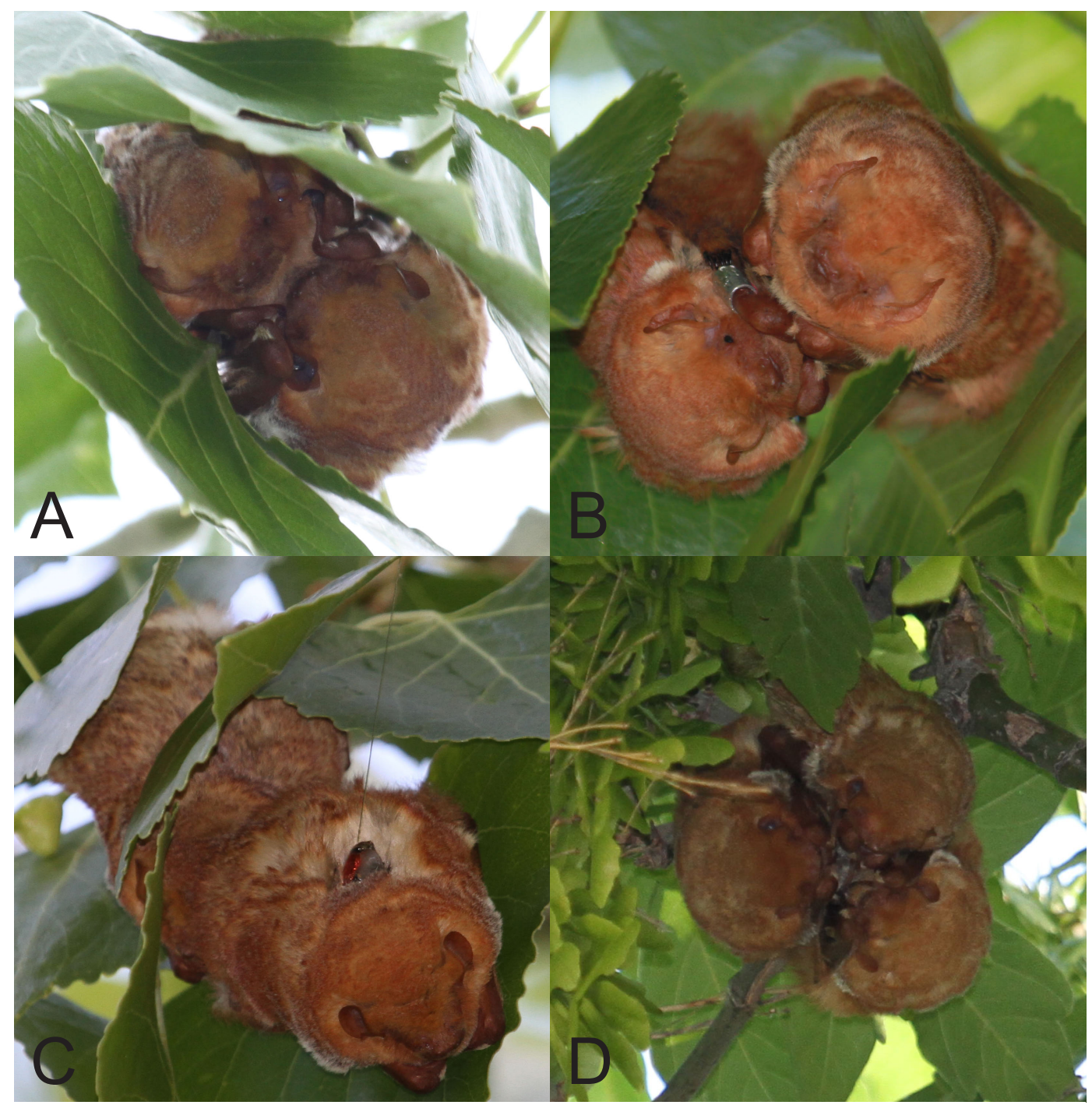

Fig. 2. Clusters of western red bats (Lasiurus blossevillii) roosting in deciduous trees along the Mimbres River in southwestern New Mexico. Panels A and B represent face-to-face pairs in cottonwoods (Populus spp.). Panel C represents a face-to-back pair in a cottonwood. Panel D represents a cluster of 3 individuals in a box elder (Acer negundo).

side. Overall, lack of selection for specific roost tree species or size suggests that use of these trees was driven by foliage density.

We did not observe western red bats using a specific orientation (i.e., directional aspect) of the tree canopy for roosting sites along the Mimbres River in New Mexico. Observations by Constantine (1959) also suggested that western red bats do not exhibit aspect selection during summer months. However, some studies have noted selection for orientation by other lasiurids (Willis and Brigham 2005, Mormann and Robbins 2007, Perry and Thill 2007, Hein et al. 2008a), whereas others have noted a lack of selection (Menzel et al. 1998, Mager and Nelson 2001). The hot, arid environment likely precludes selection for a particular orientation, as thermoregulation is equally as good in all directions. Instead, western red bats appear to roost under dense bundles of leaves and samaras, possibly in part to protect from direct solar radiation in this hot environment.

Most lasiurids are described as solitary, including western red bats (Adams 2003, 
TABLE 2. Comparison of roost tree characteristics for western red bats (Lasiurus blossevillii) between solitary and clustering individuals. Results are significant if $P<0.05$. Means are given with standard error in parentheses.

\begin{tabular}{lccc}
\hline $\begin{array}{l}\text { Tree } \\
\text { characteristic }\end{array}$ & Solitary roost & Cluster roost & $P$ \\
\hline Height $(\mathrm{m})$ & $15.2(3.4)$ & $15.7(1.3)$ & 0.63 \\
DBH $(\mathrm{cm})$ & $88.1(17.9)$ & $101.7(37.6)$ & 0.92 \\
Roost height $(\mathrm{m})$ & $9.5(1.1)$ & $8.3(2.3)$ & 0.52 \\
$\quad \begin{array}{l}\text { No. of surrounding } \\
\text { trees }\end{array}$ & $5.5(1.5)$ & $11.2(4.0)$ & 0.14 \\
$\begin{array}{l}\text { Surrounding } \\
\text { tree DBH }(\mathrm{cm})\end{array}$ & $57.0(3.1)$ & $31.5(3.6)$ & $<0.01$ \\
\hline
\end{tabular}

Harvey et al. 2011). Our observations of multiple adults roosting in clusters represent a novel behavior for this species. Constantine (1959) described finding a cluster of 3 western red bats in an orchard in California, but due to the time of year (August), it is likely that this grouping was a mother with volant young. $\mathrm{He}$ also noted that a group of 15 individuals was flushed, but it is unclear whether those bats were roosting as a group or whether they simply were driven from the same tree. Because female western red bats have 3 to 4 offspring per year (Shump and Shump 1982), a group of 15 bats could potentially consist of multiple adults with volant young. Another anecdotal record noted 4 individuals roosting together in the foliage of an exotic plant during fall and winter (Orr 1950). However, those bats were not disturbed, so the sex and age of the individuals were not recorded. For eastern red bats, the only evidence for clustering was reported in Iowa where Constantine (1966) noted 34 different clusters of bats ranging from 2 to 4 individuals. Those clusters were either described as mothers with juveniles or as mating pairs. Because our clusters were observed prior to parturition in May and early June and after the mating season, we can rule out these 2 possible explanations for this behavior. Further study is warranted to test hypotheses about why western red bats roosted in groups (i.e., microclimate, relatedness) in New Mexico, and whether this behavior is exhibited throughout the range of the species.

Due to limited observational records on roosting ecology, it is possible that the perception of the western red bat as solitary stems from the assumption that its behaviors are similar to its eastern counterpart, the eastern red bat. Menzel et al. (1998) noted a similar situation between Seminole (Lasiurus seminolus) and eastern red bats in the southeastern United States. Following a study in Georgia and South Carolina, researchers noted that the 2 species differed significantly in roost selection (Menzel et al. 1998). Ninety-seven percent of eastern red bat roosts were observed in hardwoods, whereas $94 \%$ of Seminole bat roosts were in conifers. The results from Menzel et al. (1998) and our study indicate that generalizing roost selection of lasiurids is not appropriate.

We observed that solitary western red bats switched roosts regularly, exhibiting low roost fidelity, but their roosts were located in close proximity to one another, indicating high site fidelity. Roost fidelity commonly is low among lasiurids (Menzel et al. 1998, Hutchinson and Lacki 2000, Menzel et al. 2000, Elmore et al. 2004, Mormann and Robbins 2007), but observations of high site fidelity have been described in eastern red (Menzel et al. 1998, Hutchinson and Lacki 2000, Elmore et al. 2004), Seminole (Menzel et al. 1998, Hein et al. 2008a, 2008b), northern yellow (Hein et al. 2005), and hoary bats (Veilleux et al. 2009). In our study, high site fidelity might reflect that individuals were confined to the narrow ribbon of trees in the river floodplain. In areas where habitat is more expansive for western red bats, lower site fidelity might be observed.

Clustering western red bats differed from solitary individuals by exhibiting high roost fidelity, oftentimes remaining in the same roost tree and identical locations within the canopy throughout the study, unless disturbed. Although high roost fidelity possibly resulted from limited roost availability, roost switching by solitary bats indicates that other adequate roosts were available (Lewis 1995, Carter and Menzel 2007). Interestingly, 2 individuals captured on separate nights roosted in a number of trees before being discovered in a cluster after several days of tracking. Those bats remained in the same roost from that point on; thus we likely disrupted individuals when we captured them, and frequent roost switching likely was a result of individuals trying to locate one another again. Based on these observations, we can assume that there is some association between the roost and individuals roosting in that group. Repeated use of select locations in trees might be associated with microclimate 
parameters. Alternatively, communication between individuals or olfactory cues left at the roosts, as suggested by Constantine (1966), might aid in the location of roost sites. Further research on roost and site fidelity of the western red bat is needed across its distribution to determine whether trends observed in our study are specific to this study site or are widespread throughout its distribution.

Our study on the western red bat highlights the need for additional studies on this species to provide proper management suggestions for its long-term persistence throughout its distribution. Identification of clustering behaviors, high roost fidelity for clustering individuals, and selection for tree characteristics other than size indicates that the western red bat differs in roosting ecology from other lasiurids. Likewise, such behaviors suggest that densely foliated trees along riparian corridors are important. As deciduous riparian corridors in the arid southwest continue to be threatened, preservation of densely foliated trees will aid in the long-term persistence of this uncommon foliage-roosting species in the region.

\section{ACKNOWLedgments}

We thank Kenneth Geluso, Hans Otto, Larisa Bishop-Boros, and Simon Tye for assistance in the field. We thank B.J. Schall for statistical assistance and Ginny Seamster of the New Mexico Department of Game and Fish for technical matters and land access. We thank Jeremy White, Letty Reichart, and 2 anonymous reviewers for comments on earlier versions of this manuscript. This project was funded by the Biology Department and the Research Services Council at the University of Nebraska at Kearney, the T \& E Inc. Grant Program, and the Share with Wildlife program of the New Mexico Department of Game and Fish via a State Wildlife Grant T-32-4 \#6 for the time when mammals were being inventoried on the Mimbres and Gila Rivers in southwestern New Mexico.

\section{Literature Cited}

ADAmS, R.A. 2003. Bats of the Rocky Mountain West: natural history, ecology and conservation. University Press of Colorado, Boulder, CO.

Altringham, J.D. 2011. Roosting and feeding ecology. Pages 137-174 in Bats: from evolution to conservation. 2nd edition. Oxford University Press. New York, NY.
Arnett, E.B., W.K. Brown, W.P. Erickson, J.K. Fiedler, B.L. Hamilton, T.H. Henry, A. Jain, G.D. Johnson, J. Kerns, R.R. Koford, ET AL. 2008. Patterns of bat fatalities at wind energy facilities in North America. Journal of Wildlife Management 72:61-78.

Baker, R.J., J.H. Patton, H.H. Genoways, and J.W. BickHAM. 1988. Genic studies of Lasiurus (Chiroptera: Vespertilionidae). Occasional Papers, Museum of Texas Tech University 117:1-15.

BarClay, R.M.R., E.F. BaERWALD, and J.C. GRUVER. 2007. Variation in bat and bird fatalities at wind energy facilities: assessing the effects of rotor size and tower height. Canadian Journal of Zoology 85:381-387.

Carter, T.C., And J.M. MenZel. 2007. Behavior and dayroosting ecology of North American foliage-roosting bats. Pages 61-81 in M.J. Lacki, J.P. Hayes, and A. Kurta, editors, Bats in forests. Johns Hopkins University Press, Baltimore, MD.

Carter, T.C., M.A. Menzel, and D.A. Saugey. 2003. Population trends of solitary foliage-roosting bats. Pages 41-47 in T.J. O’Shea and M.A. Bogan, editors, Monitoring trends in bat populations of the United States and territories: problems and prospects. U.S. Geological Survey ITR-2003-0003.

Coleman, L.S., K.M. Morris, and S.B. Castleberry. 2012. Characteristics of Lasiurus intermedius (northern yellow bat) roosts on Sapelo Island, Georgia. Southeastern Naturalist 11:534-536.

Constantine, D.G. 1959. Ecological observations on lasiurine bats in the North Bay area of California. Journal of Mammalogy 40:13-15.

Constantine, D.G. 1961. Locality records and notes on western bats. Journal of Mammalogy 42:404-405.

Constantine, D.G. 1966. Ecological observations of lasiurine bats in Iowa. Journal of Mammalogy 47:34-41.

Cook, J.A. 1986. The mammals of the Animas Mountains and adjacent area, Hidalgo County, New Mexico. Occasional Papers, Museum of Southwestern Biology $4: 1-45$.

Cryan, P.M. 2003. Seasonal distribution of migratory tree bats (Lasiurus and Lasionycteris) in North America. Journal of Mammalogy 84:579-593.

Dettmers, J.M., AND R.A. Stein. 1992. Food consumption by larval gizzard shad: zooplankton effects and implications for reservoir communities. Transactions of the American Fisheries Society 121:494-507.

Elmore, L.W., D.A. Miller, and FJ. Vilella. 2004. Selection of diurnal roosts by red bats (Lasiurus borealis) in an intensively managed pine forest in Mississippi. Forest Ecology and Management 199:11-20.

FEnTon, M.B. 1997. Science and the conservation of bats. Journal of Mammalogy 78:1-14.

Findley, J.S., A.H. Harris, D.E. Wilson, and C. Jones. 1975. Mammals of New Mexico. University of New Mexico Press, Albuquerque, NM.

Frick, W.F., E.F. Baerwald, J.F. Pollock, R.M.R. Barclay, J.A. Szymanski, T.J. Weller, A.L. Russell, S.C. Loeb, R.A. Medellin, and L.P. McGuiRe. 2017. Fatalities at wind turbines may threaten population viability of a migratory bat. Biological Conservation 209:172-177.

Gardner, A.L., and C.O. Handley Jr. 2007. Genus Lasiurus. Pages 457-468 in A.L. Gardner, editor, Mammals of South America. University of Chicago Press, Chicago, IL. 
Genoways, H.H., AND R.J. BaKeR. 1988. Lasiurus blossevillii (Chiroptera: Vespertilionidae) in Texas. Texas Journal of Science 40:111-113.

Gori, D., M.S. CoOper, E.S. Soles, M. Stone, R. Morrison, T.F. Turner, D.L. Propst, G. Garfin, M. Switanek, H. Chang, ET AL. 2014. Gila River flow needs assessment. A report by The Nature Conservancy. http://nmconservation.org/Gila/GilaFlowNeeds Assessment.pdf

Grinnell, H.W. 1918. Bats of California. University of California Press, Berkeley, CA.

HaLl, E.R. 1981. The mammals of North America. 2nd edition. John Wiley \& Sons, New York, NY.

HaRgRave, L.L. 1944. A record of Lasiurus borealis teleotis from Arizona. Journal of Mammalogy 25:414.

Harvey, M.J., J.S. Altenbach, and T.L. Best. 2011. Bats from the United States and Canada. Johns Hopkins University Press, Baltimore, MD.

Hein, C.D., S.B. Castleberry, and K.V. Miller. 2005. Winter roost-site selection by Seminole bats in the lower coastal plain of South Carolina. Southeastern Naturalist 4:473-478.

Hein, C.D., S.B. Castleberry, and K.V. Miller. 2008 a. Sex-specific summer roost-site selection by Seminole bats in response to landscape-level forest management. Journal of Mammalogy 89:964-972.

Hein, C.D., S.B. Castleberry, and K.V. Miller. 2008b. Male Seminole bat winter roost-site selection in a managed forest. Journal of Wildlife Management 72:1756-1764.

HumphreY, S.R. 1975. Nursery roosts and community diversity of Nearctic bats. Journal of Mammalogy 56:321-346.

Hutchinson, J.T., AND M.J. LACKi. 2000. Selection of day roosts by red bats in mixed mesophyte forests. Journal of Wildlife Management 64:87-94.

Jones, C.J. 1961. Additional records of bats in New Mexico. Journal of Mammalogy 42:538-539.

Jones, C.J. 1966. Changes in populations of some western bats. American Midland Naturalist 76:522-528.

Jones, C., AND R.D. SutTKus. 1972. Notes on netting bats for eleven years in western New Mexico. Southwestern Naturalist 16:261-266.

Kalcounis-Rüppell, M.C., J.M. Psyllakis, and R.M. Brigham. 2005. Tree roost selection by bats: an empirical synthesis using meta-analysis. Wildlife Society Bulletin 33:1123-1132.

Kunz, T.H., E.B. Arnett, W.P. Erickson, A.R. Hoar, G.D. Johnson, R.P. LARKIn, M.D. StRICKLAND, R.W. Thresher, AND M.D. TutTle. 2007. Ecological impacts of wind energy development on bats: questions, research needs, and hypotheses. Frontiers in Ecology and the Environment 5:315-324.

KunZ, T.H., AND L.F. LumsDen. 2003. Ecology of cavity and foliage roosting bats. Pages 3-89 in T.H. Kunz and M.B. Fenton, editors, Bat ecology. University of Chicago Press, Chicago, IL.

LEwIS, S.E. 1995. Roost fidelity of bats: a review. Journal of Mammalogy 76:481-496.

Mager, K.J., and T.A. Nelson. 2001. Roost-site selection by eastern red bats (Lasiurus borealis). American Midland Naturalist 145:120-126.

Menzel, M.A., T.C. Carter, B.R. Chapman, and J. LAERM. 1998. Quantitative comparison of tree roost use by red bats (Lasiurus borealis) and Seminole bat
(L. seminolus). Canadian Journal of Zoology 76: 630-634.

Menzel, M.A., T.C. Carter, W.M. Ford, B.R. ChapMAN, AND J. OZIER. 2000. Summer roost tree selection by eastern red, Seminole, and evening bats in the upper coast plain of South Carolina. Proceedings of the Annual Conference of the Southeastern Association of Fish and Wildlife Agencies 54: 304-313.

Morales, J.C., AND J.W. Bickham. 1995. Molecular systematics of the genus Lasiurus (Chiroptera: Vespertilionidae) based on restriction-site maps of the mitochondrial ribosomal genes. Journal of Mammalogy 76:730-749.

Mormann, B.M., And L.W. RobBins. 2007. Winter roosting ecology of eastern red bats in southwest Missouri. Journal of Wildlife Management 71:213-217.

Mumford, R.E., And D.A. Zimmerman. 1963. The southern yellow bat in New Mexico. Journal of Mammalogy 44:417-418.

[NMDGF] New Mexico Department of Game and FISH. 2006. Comprehensive wildlife conservation strategy for New Mexico. New Mexico Department of Game and Fish, Santa Fe, NM.

ORR, R.T. 1950. Notes on the seasonal occurrence of red bats in San Francisco. Journal of Mammalogy 31: $457-458$.

Perry, R.W., AND R.E. ThiLl. 2007. Roost characteristics of hoary bats in Arkansas. American Midland Naturalist 158:132-138.

Saugey, D.A., B.G. Crump, R.L. Vaughn, and G.A. Heidt. 1998. Notes on the natural history of Lasiurus borealis in Arkansas. Journal of the Arkansas Academy of Sciences 52:92-98.

Shump, K.A., JR., AND A.U. Shump. 1982. Lasiurus borealis. Mammalian Species 183:1-6.

Sikes, R.S., W.L. Gannon, and Animal Care and Use Committee of the American Society of MamMALOGISTS. 2011. Guidelines of the American Society of Mammalogists for the use of wild mammals in research. Journal of Mammalogy 92:235-253.

Strauss, R.E. 1979. Reliability estimates for Ivlev's electivity index, the forage ratio, and a proposed linear index of food selection. Transactions of the American Fisheries Society 108:344-352

StromberG, J.C., D.C. Anderson, And M.L. Scott. 2012. Riparian floodplain wetlands of the arid and semiarid Southwest. Pages 343-356 in D.P. Batzer and A.H. Baldwin, editors, Wetland habitats of North America: ecology and conservation concerns. University of California Press, Berkeley, CA.

Sullivan, C.L., K.D. Koupal, W.W. Hoback, B.C. PeterSON, AND C.W. Shoenebeck. 2012. Food habits and abundance of larval freshwater drum in a south central Nebraska irrigation reservoir. Journal of Freshwater Ecology 27:111-121.

Sullivan, C.L., C.W. Shoenebeck, K.D. Koupal, W.W. Hoback, and B.C. Peterson. 2011. Patterns of age-0 gizzard shad abundance and food habits in a Nebraska Irrigation Reservoir. Prairie Naturalist 43: $110-116$

Valdez, E.W., J.N. Stewart, and M.A. Bogan. 1999. Additional records of bats from the middle Rio Grande Valley, New Mexico. Southwestern Naturalist 44:398-400. 
Veilleux, J.P., P.R. Moosman JR., D.S. Reynolds, K.E. LaGory, and L.J. WaLSTON JR. 2009. Observations of summer roosting and foraging behavior of a hoary bat (Lasiurus cinereus) in southern New Hampshire. Northeastern Naturalist 16:148-152.

WaLsberG, G.E. 1986. Thermal consequences of roostsite selection: the relative importance of three modes of heat conservation. Auk 103:1-7.

Willis, C.K.R., AND R.M. BRigham. 2005. Physiological and ecological aspects of roost selection by repro- ductive female hoary bats (Lasiurus cinereus). Journal of Mammalogy 86:85-94.

ZaR, J.H. 1999. Biostatistical analysis. 4th edition. PrenticeHall, Upper Saddle River, NJ

Received 1 June 2017

Revised 8 March 2018

Accepted 10 April 2018

Published online 19 July 2018 